\title{
Digital landscapes. How digitalization impacts business
}

\author{
Fabio Cassia interviews Timothy O' Connell, Accelerator \\ Director H-FARM Spa
}

As H-FARM Accelerator Director you have witnessed a lot over the past years in terms of what has been happening in the world of startups and how digitalization is affecting business, particularly in Italy. What does digitalization mean for traditional business?

I think we should start with a paradox. We still use the word digital or digital landscapes as something that is separate from what we are doing, which is the business itself, whereas today business and digital have become the same thing. It would almost be like talking fifty years ago about electricity and discussing about electric landscapes. Business without digital today almost does not exist. There are very few examples where digital is not a central part of the business and the strategy of how you can capture the market and of how a company can grow. I think that probably in the next five years, we will no longer even use the word digital. We will just be talking about business and how digital will be part of that process.

Looking back, what are the main processes that have shaped the digital landscape as we know it today?

These processes started in 2000. What really emerged and what was really important about that period was the whole concept of contribution, sharing and collaboration. This is something that is even more important today and we are now seeing it even more active. It is something that was emerging as we were seeing the first fall of the Internet bubble. As this continues, we can see it more and more obviously in education and in other areas, such as business. The concept of collaboration and the concept of sharing have become more and more important.

\footnotetext{
How do you apply these concepts of sharing and collaboration in H-FARM?

In H-FARM, we are always attempting to find ways to collaborate with others who are working in the same field around the world. For example, at the European Accelerator Summit that we host in H-FARM, we invite the 50 top accelerators that work with startups around Europe to come and share their experiences. It's about talking, discussing, sharing. We have actually banned PowerPoint slides - we are not going to sit there and look at slides, we are going to discuss and figure out what is working and what it is not working (what works in Finland, what works in Madrid, what is not working in the UK, and so on). This is a wonderful opportunity for all of us to learn and share and collaborate. Another example about the importance
} 
sinergie Vol. 35, N. 103, 2017

of sharing and collaboration is the new group of startups that just arrived in H-FARM. We have teams from South Africa, Canada, Denmark, UK, Germany and only two from Italy. However, what we found is that the Italian teams grow faster when paired with these European teams because they are challenged more. What is more interesting is that the Italian businesses that collaborate with us are more stimulated to come and work with H-FARM because they love getting input from around the world.

Going back to the topic of digital landscapes, what were the milestones of their evolution after 2000 ?

I would say the introduction of iTunes, Wikipedia, social networking, and, above all, the introduction of the iPhone in 2007. The arrival of the iPhone enabled the birth of the app-economy. So many industries have been completely revolutionized because of this one tool, such as the rise of Uber, Airbnb, etc. I heard a statistic the other day that 75 million people sleep in people's houses through Airbnb per day! We just have to imagine someone back in 2008 (not an eternity ago), if someone said to you, "Hey, the house that you are renovating will be part of a network that has 75 million people sleeping in other people's houses in a few years".

So, as we go forward, Airbnb and the Makers Movement which started out in 2013 more or less, and the arrival of crowdsourcing and crowdfunding, the Kick Starter and Indiegogo. This was another interesting transformation because everyone was saying at the early stage of this period that it was all about apps and digital, and it was not really about the real economy.

And so we come to the digital landscapes as they are today.

In 2000 there were 394 million people online, while in 2014, there were three billion. Now $40 \%$ of the world's population is online. Three billion people that can buy products, services, communicate, share and collaborate around the world. And that will grow dramatically very soon because there are some amazing projects being done by firms like Google on how to get India and African countries online. And these people will become very important consumers for a lot of very important goods. That is an amazing opportunity. If I run a small or medium enterprise, making anything in the world, I will have an unlimited amount of opportunities. The question is how to get there. How to get in contact with people who want to build new products, how to get in contact with people who want to buy new products, how to get in contact with people who want to develop something which is new, but maybe they do not have the experience. This is what the world is offering now.

What are the impacts of these digital landscapes on the real economy?

Technology is both dramatically changing social behaviors and creating a lot of new products and services.

\section{Let's start with behaviors, what are the main changes and trends going on?}

Technology is changing the way we live. For example, the way that we pay: how many of us have been at a bank in the past month? It is changing 
the way we research our vacations: how many of us have been to a travel agency in the past year? We basically do everything online and most of us who travel a lot do everything using our phones. You don't even bother with the computer because you can book your flight and do your checkin directly from the phone. This has been made possible just in the past five years. The travel agencies and the whole travel industry are just being completely turned on their head. It also changes the way we discover and listen to our music. Right now, it's just a matter of selecting between Spotify and Apple music.

It even changes the way we are furnishing our homes. I remember talking to some of the largest furniture manufactures a few years ago at Salone del Mobile and they told me "Yes, this is great for all the other issues, but it will never affect the design industry, because customers want to see the product, touch the product." This is completely untrue. In the US, people only buy furniture online. They have no interest in going into an old showroom, with old, dusty furniture sitting around. They want to see it into their house, they want a 3D model and they want to order it and they want it there the next day. It has completely changed the way people buy. People in China buy everything online through IKEA or other outlets and have everything shipped home. This is a huge opportunity.

It changes the way we consume things. People want to know where things are produced, how they are produced and who produced it. We have sensors which allow people to understand the whole supply chain of any product.

\section{And what about changes in education?}

Of course technology is changing the way in which we learn, as well. We need to ask ourselves how is education going to take place in the next 10-15 years. In the US, with an online learning system you can follow every single Stanford, Berkeley, Harvard course online for free. There is no reason why somebody has to pay to go to university just to do the course work. The value added that you need to have as a university system is to go beyond the interaction in the classroom. It must be much greater and a lot of universities are making the shift. For example, Olin College of Engineering has completely turned on its head they way in which engineering is taught and this is going to happen in every area. I think management is, of course, going in the same direction. Alt School is a great experiment that is happening in Palo Alto but in Brooklyn and other places in the US, there are other experiments in the ways in which we are teaching children. We are basically using a similar model in H-FARM with the new studio complex that is being launched. The first high school students that will arrive this Fall in H-FARM will be using these styles and methods. Everyone thinks it's about having an iPad in the classroom but it has nothing to do with that. It is how you approach understanding, interaction, how you approach solving problems. It is a completely different approach to education.

And the pace of these changes is getting faster...

Yes, it's funny when we see that some people just assume that things have always been this way and it's also funny that all of the things that they
Fabio Cassia

Timothy O' Connell

Digital landscapes. How

digitalization impacts business 
sinergie Vol. 35, N. 103, 2017

are working on were not possible five years ago. It is amazing to see how that changes, how quickly it is occurring and that it is very difficult today to talk about strategy or to talk about business without knowing almost on a daily basis what is happening in the market place. Today, technology is accessible, cheaper. This is another thing people do not realize. In 2007, $3 \mathrm{D}$ printing cost $\$ 40,000$, now a printer is just $\$ 300$. There will actually be another leap - we have a startup that has a printer that costs $\$ 150$. In 2007 , a drone was $\$ 100,000$, now they cost $\$ 700$ or even less. Another example is DNA sequencing- in 2007, the price was $\$ 10,000,000$. In 2015 , it was $\$ 99$ for a kit. I was in a DNA lab in Trento, three weeks ago and they were showing me the new DNA sequencing equipment that they had just bought from the US. It's amazing! You have a little box, you do a test and they give you your entire sequencing in a matter of days. It is changing the way that the medical and the healthcare system will work in the coming years.

So, you mentioned that these digital landscapes are impacting the real economy in two ways: by changing behaviors and by creating a lot of new products and services. We have discussed behaviors, but what about products and services?

Great technology is nothing without innovative products, services and business models. Have you ever studied the whole history of Edison? We all know that Edison brought electricity to the market. The biggest problem is that he invented what was going to be done with the light bulb and he himself knew what to do with electricity, but there was nobody that understood how it could be used for business. He spent the last twenty years of his life trying to invent the business models and the products and services that use electricity. That is the stage in which we find ourselves today with digitalization. The difference is that we are doing it in a matter of months, as opposed to years.

Think about monitoring. Funnily enough this was such a hot topic for the past two years: the monitoring with Fitbit, with Apple Watch, etc. This is an area that we feel is still very interesting, but it is still an area that does not have a clear future. We are monitoring a lot of things and it helps us to understand a lot, but we are nowhere close to what this can really do for a person. This is still an area where we have not found its future use and its true essence. There are so many groups such as Apple that are looking how to do this, but they still have not found the answer. In the healthcare industry, we still think there is a lot of room to improve.

Think about the Google Car. This is not a possible future opportunity, this is a certainty. We will have self-driving cars in the next decade. All of us of a certain age think this is science fiction but it is no longer science fiction. What we do not yet understand is what this means. What does it mean not to have to drive your car? What does it mean to be able to spend two or three hours instead of focusing on the road, to do other things? What other things can you do in your car? This is the opportunity - to understand everything that revolves around the fact that we will have to stop driving cars. We have no doubt. The question is what related business models you can create. 
Could you give also us an example of a new and successful product or service made possible by digitalization?

Look at the way environments work. Groups such as Nest and Amazon are developing great products that are super cheap and that allow us to control the environment in which we live. Half of the trucks on the streets of cities such as Seattle, New York and San Francisco are the green trucks of Amazon Fresh. Amazon is substituting the supermarkets in the major metropolitan cities in the US through a system where you order what you need, anytime, anywhere, either at work or at home and it is delivered directly to your home. This idea was around the Internet in the 2000s, so it's not a new idea. This is something which had failed dramatically and was probably one of the worst Internet failures in 2000. However today, it actually works. And it is taking over. When you are in Seattle, you see thousands of these trucks. Why does it work? Because they made it simple. They use dash buttons for over one thousand products and now anyone can put a dash button on products around your house, so that children, mothers and fathers can just push the button when the product is finished and it arrives the next morning. If you are washing your clothes and you finish the detergent, you do not have to think about adding it to the list, you just push the button. The next day the product is at your house.

And what about the changes in the process itself offunding and developing new products or services?

The fact that you can launch and fund a product and a service through sharing and through co-sourcing is a huge opportunity. In the US and probably Northern Europe, this approach has already been used for almost every product and service. Nike launched and funded a new product a few months ago through crowdsourcing because it was so innovative. They thought, "Why should we take all the risks? Let our passionate users take the risk". And they put the idea into crowdsourcing. People actually paid the company before they even produced the product. It makes sense. Why would you not do that in every industry? If you have a brand new idea, let the users pay for the development.

To what extent do you think that traditional businesses - and in particular Italian businesses - are aware of these landscapes and are ready to deal with them?

Recently I had a discussion with a leading bank and we were talking about what will happen to the banking industry. Let's say the result of the discussion was very clear: we have no idea. We have literally no idea in five years where the banking industry is going to be (and I was speaking with a large, major bank). The thing that always worries me - I also work with some of the local banks here in Italy - is that they just have no idea of the train that is coming. All of these branches, all of the ways they do business, the risk is that they may not even exist anymore in five years. We all need to be very aware of that and learn what we can do with all of those great resources we have, all the great experience, all these people. If I was working in a bank right now, of course I would be scared to death. I would be scared about all the people who are probably going to be out of a job 
sinergie Vol. 35, N. 103, 2017

soon, but at the same time there is an enormous amount of opportunities at banks, how to help people sell, how to help people manage their money. There are thousands of opportunities.

This is the future and we have just started to understand it here in Italy. Here, we have centuries-old know-how and we are just starting to realize how we can approach the future. When you are looking at a traditional Italian region where you have very specific industries that are building chairs, and other furniture, the thinking has always been, "This transition is not going to affect us". Well, that is not true anymore. Because through the Makers Movement, through platforms like Kickstarter, even somebody in their house who is sitting anywhere (in Sicily, in Finland or in the US), can actually start developing a product now. A great opportunity that a region has is to be the maker of that world. You have designers and creators all over the world thinking of new ideas and this region has the practical experience of how to produce those products. Again, there is no logical reason why designers and furniture manufacturers should not be $100 \%$ e-commerce. They give you all the reasons in the world. It is because of the sales channels, because of their agents. This is absolute garbage. There is no way they can defend the fact that they are not online.

The pace of change is so fast that it is difficult to make any forecast about the future. But can you share with us some of your views about the future?

I think that the Internet and digitalization are parts of a new ecosystem based on a new language that is going to pervade every single element of business. That is why I think that within five years - maybe even sooner - we will no longer talk about the Internet, we will no longer talk about digital, we will probably no longer talk about mobile. It will be something that you will not even think about. The idea that you actually have to go online, connect, look for wi-fi...this will no longer exist. Everything my kids will do will be connected and everything they do will be digital. When they shop, when they learn, when they go to the hospital, everything will be permitted by this process. Our job is to understand what we can do today to make this useful to help our enterprises and our industries grow.

We are in an ecosystem composed of products, appliances, platforms and learning machines that are all driven by users. Every solution, every product, every service has one end in mind: what the user needs. And when you can resolve that problem and you have something that is truly useful for resolving a user's need, then you have a business. When I discuss this issue with traditional companies, I often see very strange reactions. Somebody that is used to running a small bank or running a small factory, when asked, "What does your user need?", their typical response is, "They need a product, they need to buy my chairs." But that is not what the user actually needs.

How will this new scenario in which the Internet has become a new ecosystem and data has become a new language affect the role of management?

I literally cannot think of any other period in history in which almost anyone in the world could have access to the amount of information we have today. I read a very controversial article recently arguing that 
basically every core concept that teachers try to have students learn, an average student can find it in 15 seconds. Access to the Internet basically gives you access to answers in any area, the core understanding has become less and less important. The real value is how to find or how to manage solutions and problems. Today, you have access to anything and everything you could want in the world. The problem is you need to have the experience to know what to do with that information. I know there is a thought that management will no longer exist in ten years, that it will no longer be needed. I think the exact opposite is true. I think we will have more and more information and opportunities and what we need is to train people on how to use this information to solve problems and how to create solutions. Moreover, most of the time the issue is not finding the solution to the problem, but it's understanding what the need is. People often find themselves going around in circles when the real question is, "What do you really need?" I remember that once we had a long discussion with some startup teams. "Do you need more money? Do you need more time? Do you need more happiness? What is it that you need in life? Why is it so complex to identify what is your true need?". "I need to sell more". "Why do you need to sell more? What is your true need? Is it just because you need more money in the bank?". "No, I need to sell more to be able to pay my workers". "So, you need more activity?". You need to understand what the need is and that is where I think that management is going to continue being an enormous topic. That is the greatest opportunity. Using creative solutions to respond to creative problems.

Finally, what do you think your and our jobs will look like in the near future?

I think all of us, including myself, are going to be obsolete in about two or three years. I have no doubt I will be obsolete, if I am not every single day looking to understand how this change is going to affect us. For example, I will basically tell everyone that there is no reason why in five years we will need accelerators, because that is what universities will do, I believe. What we do today, I think, will no longer be useful, which is one of the reasons why H-FARM is investing so much on education, because we think what we are doing today is just another form of education. Therefore, I think that we do need to be afraid, but there is no reason why we cannot re-invent what we are doing. It is all out there. All of this opportunity, all of this knowledge, all of this understanding. You just need to figure out how to use it.

\section{Academic or professional position and contacts}

Fabio Cassia

Researcher of Management

University of Verona - Italy

e-mail: fabio.cassia@univr.it

Timothy O' Connell

Accelerator Director H-FARM Spa - Roncade, Treviso Italy

e-mail: timothy@h-farm.com 